\title{
Production of Extra-Cellular Proteases from Marine Bacillus Sp. Cultured in media containing Ammonium Sulfate as the sole Nitrogen source
}

\author{
Seri Intan, M. ${ }^{\star}{ }^{\star}$, Haslinda $\mathbf{H}^{2}{ }^{2}$, Mariatul Fadzillah $\mathbf{M}^{3}$, \\ Ishak, M.Y. ${ }^{4}$ and Syed Osthman, S.Z ${ }^{5}$ \\ ${ }^{1,4,5}$ Environmental and Bioprocess Technology Centre (Building 19), SIRIM Bhd, \\ P.O. Box 7035, 40911 Shah Alam, Selangor D.E \\ ${ }^{2,3}$ Kulliyah of Engineering, University Islam Antarabangsa Malaysia, \\ Jalan Gombak, 53100 Kuala Lumpur. \\ Email: intan@sirim.my
}

\begin{abstract}
Useful bacterial strains can be used to increase mineralize activity of an aquatic system. These bacteria can specifically degrade targeted compound by producing extra-cellular enzymes. Three species of Bacillus i.e. B. subtilis, B. pumilus and $B$. licheniformis acquired from shrimp ponds were tested for their ability to utilize ammonia and produce extracellular enzymes. These bacteria were grown in artificial seawater (30 ppt salinity and $\mathrm{pH} 7.6$ ) supplemented with decreasing yeast extract concentration but increasing ammonium sulfate concentration. All three bacteria grew in artificial seawater containing only $0.01 \%$ yeast extract and $1 \%$ ammonium sulfate. However, only $B$. pumilus and $B$. licheniformis were able to grow in the medium containing only $1 \%$ ammonium sulfate as a sole energy source. Bacterial growth reduced when alkaline proteases activities was maximum from culture filtrates of all three bacterial cultures during 24 hour culturing in artificial seawater containing $0.01 \%$ yeast extract and $1 \%$ ammonium sulfate at $30^{\circ} \mathrm{C}$ when assayed at $\mathrm{pH}$ 9. Bacterial growth increased when acid proteases activities was maximum from culture filtrates of all three bacterial cultures during 48 hour culturing in artificial seawater containing $0.01 \%$ yeast extract and $1 \%$ ammonium sulfate at $30^{\circ} \mathrm{C}$ when assayed at $\mathrm{pH} 5$.
\end{abstract}

Keyword: Bacillus, ammonia utilization, extra-cellular enzymes

\section{INTRODUCTION}

In intensive culture systems, water quality normally deteriorates quickly due to accumulation of excess artificial feed as well as the excreta of cultured organisms, which contributes to high toxic compounds such as ammonia. Most aqua-culture ponds are facing difficulty in controlling the buildup of excess minerals especially nitrate and ammonia in their confined systems. This problem contributed to high mortality rate, poor product flavour, reduced growth rate and significant loss of revenue (Moriarty, 1999).

Useful microbes can be used to increase mineralize activity of the aquatic system (Devaraja et al., 2002) through production of extra-cellular enzymes. Hydrolysis of peptidic compounds by extra-cellular microbial peptidases is the key for the mobilization of ammonia and subsequent nitrogen cycling processes in an ecosystem (Bach et al., 2001). Microorganisms represent an excellent source of enzymes owing to their broad biochemical diversity and their susceptibility to genetic manipulation (Rao et al., 1998). Nitrifying bacteria have significant functions in the nitrogen cycle, which involves the conversion of ammonia to nitrite and the subsequent conversion of nitrite to nitrate. During the process of nitrification, nitrifying bacteria detoxify ammonia in two steps. First, Nitrosomonas spp. converts toxic ammonia to

\footnotetext{
* Corresponding author.
}

nitrite, which is also toxic to fish. Then in the second step, nitrite is converted to nitrate by the Nitrobacter spp., which is not considered toxic unless it accumulates in high concentrations (Straub and Dixon, 1997). Alternative to nitrifying bacteria, heterotrophic bacteria can also be used to supplement or replace true nitrifying bacteria because heterotrophic bacteria are able to tolerate a wider range of environmental conditions (Straub and Dixon, 1997). Many of the heterotrophic bacteria used in these products are also capable of forming spores allowing the product to be dried, packaged and sold as a viable culture.

$B$. subtilis is an ubiquitous bacterium commonly recovered from water, soil, air and decomposing plant residue that contributes to nutrient cycling when biologically active due to the various enzymes produced by members of the species. Many species of the genus Bacillus produce a variety of extra-celllular and intracellular proteases (Valbuzzi et al., 1999) and being used extensively for the production of industrial enzymes such as amylase and proteases (Fleming et al., 1995).

Several Bacillus $s p$ are now being used to produce commercially available fertilizer for soil and 'nitrifier' for aquaculture system due to their ability to breakdown complex protein and organic matter into ammonia, then to nitrite and finally to nitrate.

This work describes the ability of $B$. subtilis, $B$ licheniformis and $B$. pumilus locally isolated from 
seawater, in utilizing ammonia as their energy source. The ability of Bacillus sp. in utilizing ammonia can be used in bioremediation of aquatic ecosystem especially for shrimp culture where excess ammonia is toxic to the shrimp health.

\section{MATERIAL AND METHODS}

\section{Bacterial Strains}

Bacillus subtilis, Bacillus licheniformis and Bacillus pumilus used in this study were provided by Prof. Dato' Dr Mohamed Shariff (University Putra Malaysia). Stock cultures of Bacillus sp. were maintained on Tryptic Soy Agar (TSA) (Difco) and stored at $4^{\circ} \mathrm{C}$ until required. For a long-term storage, $0.5 \mathrm{ml}$ of bacterial cultures were transferred into $2 \mathrm{ml}$ cryotube containing $0.5 \mathrm{ml}$ of $20 \%$ glycerol and kept at $-80^{\circ} \mathrm{C}$ until required.

\section{Media and culture conditions}

To determine the ability of the Bacillus $s p$. to grow in seawater, a single colony was transferred from TSA into artificial seawater mixture (Sigma) containing $0.2 \%(\mathrm{w} / \mathrm{v})$ $\mathrm{CaCl}_{2}, \quad 0.015 \% \quad(\mathrm{w} / \mathrm{v}) \mathrm{KBr}, 1.22 \%$ (w/v) $\mathrm{MgCl}_{2} \cdot 6 \mathrm{H}_{2} \mathrm{O}$, $0.075 \%(\mathrm{w} / \mathrm{v}) \mathrm{KCl}, 0.58 \%(\mathrm{w} / \mathrm{v}) \quad \mathrm{MgSO} 4.7 \mathrm{H} 2 \mathrm{O}, 2.38 \%$ (w/v) $\mathrm{NaCl}, 0.03 \%$ (w/v) $\mathrm{NaHCO}_{3}, 0.36 \%$ (w/v) $\mathrm{Na}_{2} \mathrm{SO}_{4}$ and $0.005 \%(\mathrm{w} / \mathrm{v}) \mathrm{SrCl} 3.6 \mathrm{H} 2 \mathrm{O}$ at $30 \mathrm{ppt}$ salinity and $\mathrm{pH}$ 7.6. The artificial seawater was supplemented with yeast extract of the following final concentration $(\mathrm{w} / \mathrm{v})$ of $0.5,0.1$, $.05,0.025,0.01$ and 0 . To determine their abilities to utilize ammonium sulfate as their sole energy source, varying final concentration $(0,0.25,0.5,0.75$ and 1$)$ of ammonium sulfate were added into the media. The culture was grown at $30^{\circ} \mathrm{C}, 100 \mathrm{rpm}$ in a $10 \mathrm{ml}$ medium in a $25 \mathrm{ml}$ Universal bottle. After 24 hour, a score was given to describe the turbidity of each culture in order to estimate their growth. Then $1 \%$ volume of the culture from the Universal bottles was transferred into fresh artificial seawater supplemented with $0.01 \%$ yeast extract and $1 \%$ ammonium sulfate in a $50 \mathrm{ml}$ medium in a $250 \mathrm{ml}$ conical flask. These cultures were grown for 96 hour at $30^{\circ} \mathrm{C}$ and $200 \mathrm{rpm}$.

\section{Culture growth measurements}

For initial acclimatization experiment, growth was estimated from turbidity of $10 \mathrm{ml}$ culture grown for 24 hour in the $25 \mathrm{ml}$ Universal bottles. For shake flask culture, every 24 hour, optical density (OD) at $600 \mathrm{~nm}$ was measured and sample was taken from culture broth to estimate the colony forming unit (CFU). $\mathrm{OD}_{600}$ was measured using an UV-visible spectrophotometer (Hitachi, Japan). CFU was calculated from culture grown on TSA (Difco) incubated for 24 hour at $30^{\circ} \mathrm{C}$.

\section{Protease assay}

To prepare a cell-free broth, $1 \mathrm{ml}$ of bacterial culture in a sterile $1.5 \mathrm{ml}$ Eppendorf tube was centrifuged at 13,000 rpm. The supernatant was transferred to a sterile $1.5 \mathrm{~m}$ Eppendorf tube and kept frozen until needed for protease assay. Protease activity was determined according to Brock et al. (1982). Protease activity was determined by adding $50 \mu \mathrm{l}$ of the cell-free broth to a $1 \mathrm{ml}$ reaction buffer containing $0.5 \mathrm{ml}$ of either $0.3 \mathrm{M}$ sodium acetate/acetic acid at $\mathrm{pH} 5.0$ or $0.3 \mathrm{M}$ sodium borate at $\mathrm{pH} 9$, each with $0.5 \mathrm{ml}$ of $10 \mathrm{mg} / \mathrm{ml}$ azocasein (Sigma, U.K.). The mixture was incubated for $2.5 \mathrm{~h}$ at $30^{\circ} \mathrm{C}$. The reaction was terminated by the addition of $100 \mu \mathrm{l}$ of $70 \%(\mathrm{w} / \mathrm{v})$ tricholoacetic acid (TCA) to give a final concentration of $6 \%(\mathrm{w} / \mathrm{v})$. The samples were centrifuged at $12,000 \times g$ in a 5415D Centrifuge (Eppendorf, Germany) for $3 \mathrm{~min}$ and $0.5 \mathrm{ml}$ of the resulting supernatant was transferred to an Acryl cuvette containing an equal volume of $1 \mathrm{M} \mathrm{NaOH}$ and its $\mathrm{OD}_{450}$ was determined in $150-20$ spectrophotometer (Hitachi, Japan).

\section{RESULTS AND DISCUSSIONS}

Bacterial cultures containing only $0.5 \%$ yeast extract were observed to be most turbid with score 10 (Table 1). However, in the culture containing $0.5 \%$ yeast extract and varying ammonium sulfate concentration, the turbidity score starts to decrease (Table 1). Eventhough, both yeast extract and ammonium sulfate provided source of nitrogen for the bacteria but at high percentage of both sources, the growth of the bacteria was inhibited. When grown on $0.1 \%$ yeast extract, the addition of ammonia sulfate into the media does not alter the turbidity score of all strains (Table 1 ). When grown on $0.05 \%$ yeast extract, the turbidity score was 1 , addition of ammonia at $1 \%$ managed to increase the turbidity score to $5 / 4$ (Table 1 ). When grown below $0.025 \%$ yeast extract the turbidity score was 0 , with the addition of ammonia at $1 \%$ the turbidity score was maintained above 3 (Table 1). When only $1 \%$ ammonium sulfate was used, only $B$. licheniformis and B. pumilus were shown to have turbidity scores of 2/1 (Table 1). All Bacillus sp. tested were able to utilize ammonia as sole nitrogen source when other source of nitrogen such as yeast extract was limited. Bacillus subtilis uses glutamine as the best source of nitrogen however, in the absence of glutamine, alternative nitrogen sources such as ammonium can be used (Detsch and Stulke, 2003).

The result from Table 1 has shown that $0.01 \%$ yeast extract does not influence the growth of the bacteria. Therefore, this medium was used with $1 \%$ of ammonia sulfate for further studies on the influence of ammonia on growth and production of extra-cellular enzymes by Bacillus sp.

In artificial seawater supplemented with $0.01 \%$ yeast extract and $1 \%$ ammonium sulfate, the turbidity $\left(\mathrm{OD}_{600}\right)$ and CFU count of $B$. pumilus and $B$. subtilis cultures decreased during the first 24 hour of culturing and then increased steadily until the end of the incubation period at $96 \mathrm{hr}$ (Figure 1 and Figure 2). In comparison, $B$. licheniformis did not show similar growth pattern and has steady increased in culture turbidity at $\mathrm{OD}_{600}$ and CFU count (Figure 1 and Figure 2). All bacterial strains were 
Table 1. Culture turbidity score for Bacillus $s p$ grown in artificial seawater supplemented with varying percentage of yeast extract and ammonium sulfate $\left(\left(\mathrm{NH}_{4}\right)_{2} \mathrm{SO}_{4}\right)$.

\begin{tabular}{|c|c|c|c|c|c|c|c|}
\hline \multirow{2}{*}{ Media } & \multirow{2}{*}{ Without $\left(\mathrm{NH}_{4}\right)_{2} \mathrm{SO}_{4}$} & \multicolumn{5}{|c|}{$\left(\mathrm{NH}_{4}\right)_{2} \mathrm{SO}_{4}$} & \multirow{2}{*}{ Strains } \\
\hline & & $0.1 \%$ & $0.25 \%$ & $0.5 \%$ & $0.75 \%$ & $1.0 \%$ & \\
\hline \multirow{4}{*}{$\begin{array}{c}0.5 \% \\
\text { yeast extract }\end{array}$} & 10 & 10 & 9 & 7 & 6 & 6 & \multirow{4}{*}{$\begin{array}{l}\text { B. pumilus } \\
\text { B. subtilis } \\
\text { B. licheniformis } \\
\text { Control }\end{array}$} \\
\hline & 10 & 9 & 8 & 8 & 5 & 5 & \\
\hline & 10 & 10 & 9 & 7 & 6 & 6 & \\
\hline & 6 & 0 & 0 & 0 & 5 & 0 & \\
\hline \multirow{4}{*}{$\begin{array}{c}0.1 \% \\
\text { yeast extract }\end{array}$} & 5 & 6 & 5 & 7 & 5 & 5 & \multirow{4}{*}{$\begin{array}{l}\text { B. pumilus } \\
\text { B. subtilis } \\
\text { B. licheniformis } \\
\text { Control }\end{array}$} \\
\hline & 5 & 4 & 4 & 6 & 6 & 6 & \\
\hline & 5 & 5 & 5 & 4 & 6 & 5 & \\
\hline & 3 & 3 & 0 & 0 & 0 & 0 & \\
\hline \multirow{4}{*}{$\begin{array}{c}0.05 \% \\
\text { yeast extract }\end{array}$} & 1 & 0 & 0 & 0 & 0 & 5 & \multirow{4}{*}{$\begin{array}{l}\text { B. pumilus } \\
\text { B. subtilis } \\
\text { B. licheniformis } \\
\text { Control }\end{array}$} \\
\hline & 1 & 0 & 0 & 0 & 0 & 4 & \\
\hline & 1 & 0 & 0 & 0 & 0 & 5 & \\
\hline & 1 & 0 & 0 & 0 & 0 & 0 & \\
\hline \multirow{4}{*}{$\begin{array}{c}0.025 \% \\
\text { yeast extract }\end{array}$} & 0 & 0 & 0 & 0 & 0 & 4 & \multirow{4}{*}{$\begin{array}{l}\text { B. pumilus } \\
\text { B. subtilis } \\
\text { B. licheniformis } \\
\text { Control }\end{array}$} \\
\hline & 0 & 0 & 0 & 0 & 0 & 4 & \\
\hline & 0 & 0 & 0 & 0 & 0 & 4 & \\
\hline & 0 & 0 & 0 & 0 & 0 & 0 & \\
\hline \multirow{4}{*}{$\begin{array}{c}0.01 \% \\
\text { yeast extract }\end{array}$} & 0 & 0 & 0 & 0 & 0 & 2 & \multirow{4}{*}{$\begin{array}{l}\text { B. pumilus } \\
\text { B. subtilis } \\
\text { B. licheniformis } \\
\text { Control }\end{array}$} \\
\hline & 0 & 0 & 0 & 0 & 0 & 3 & \\
\hline & 0 & 0 & 0 & 0 & 0 & 3 & \\
\hline & 0 & 0 & 0 & 0 & 0 & 0 & \\
\hline \multirow{4}{*}{$\begin{array}{c}0 \% \\
\text { yeast extract }\end{array}$} & 0 & 0 & 0 & 0 & 0 & 1 & \multirow{4}{*}{$\begin{array}{l}\text { B. pumilus } \\
\text { B. subtilis } \\
\text { B. licheniformis } \\
\text { Control }\end{array}$} \\
\hline & 0 & 0 & 0 & 0 & 0 & 0 & \\
\hline & 0 & 0 & 0 & 0 & 0 & 2 & \\
\hline & 0 & 0 & 0 & 0 & 0 & 0 & \\
\hline
\end{tabular}

Growth rating : 0 (less growth) --- 10 (more growth)

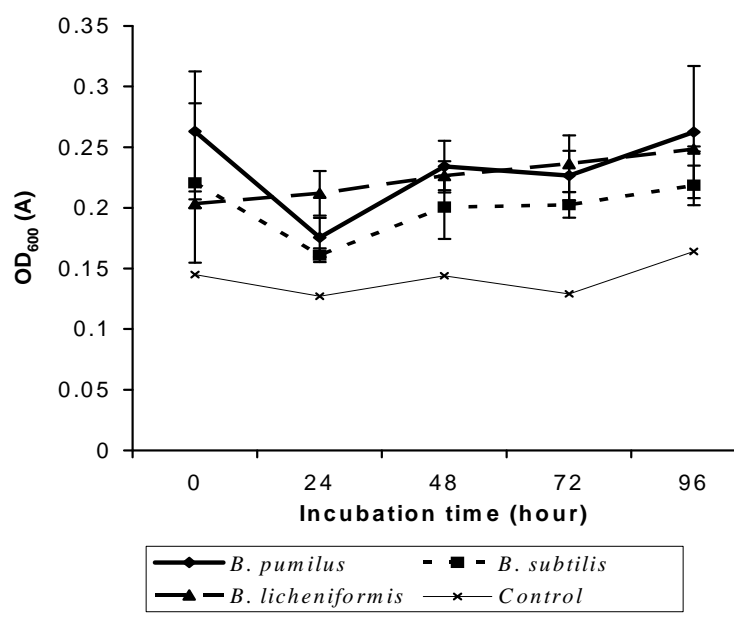

Figure 1:Optical density at $600 \mathrm{~nm}$ of Bacillus $s p$. cultures grown in artificial seawater supplemented with $0.01 \%$ yeast extract and $1 \%$ ammonium sulfate at $30^{\circ} \mathrm{C}$ and $200 \mathrm{rpm}$.

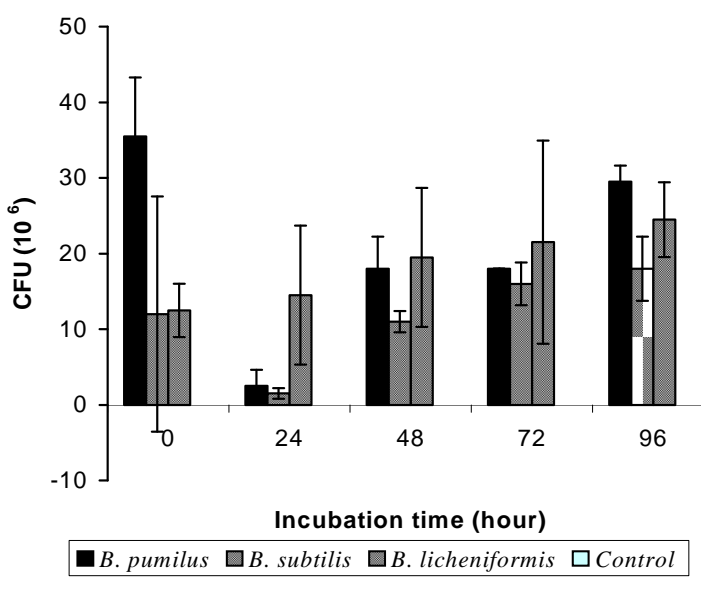

Figure 2: olony forming unit (CFU) of Bacillus $s p$. cultures grown on tryptic soy agar (TSA) from culture grown in artificial seawater supplemented with $0.01 \%$ yeast extract and $1 \%$ ammonium sulfate at $30^{\circ} \mathrm{C}$ and $200 \mathrm{rpm}$. 
able to increase and maintain their growth until the end of incubation at 96 hour by utilizing yeast extract, ammonia and cell debris.

During the first 24 hour of culturing, a decreased in bacterial cultures turbidity at $\mathrm{OD}_{600}$ and CFU count (Figure 1 and figure 2) was followed by an increased in alkaline protease activity detected from cell-free broth of the bacterial culture assayed at $\mathrm{pH} 9$ (Figure 3). During the first 24 hour of culturing, $B$. pumilus produced highest activities of alkaline proteases followed by $B$. subtilis and $B$. licheniformis (Figure 3 ). During 48 hour culturing, an increased in bacterial cultures turbidity at $\mathrm{OD}_{600}$ and CFU count (Figure 1 and figure 2) was followed by a decreased in alkaline proteases activities detected from cell-free broth of the bacterial culture assayed at $\mathrm{pH} 9$ (Figure 3).

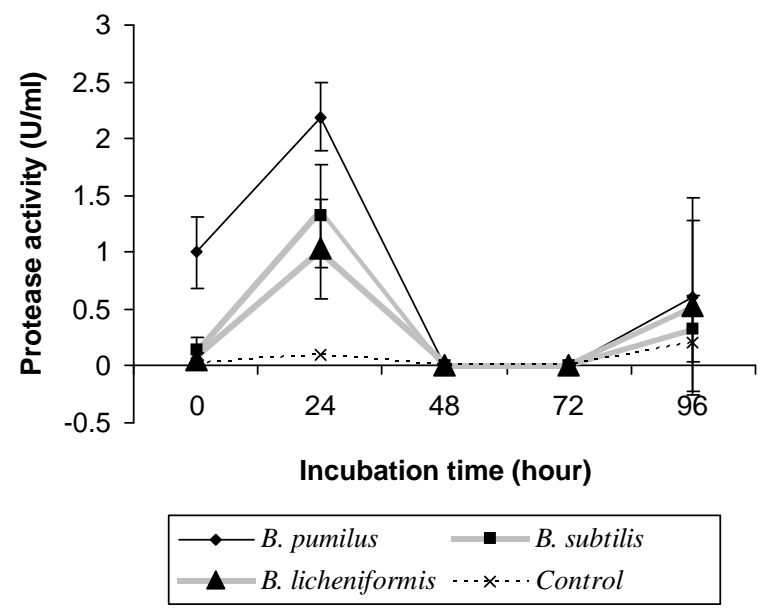

Figure 3:Protease activity at $\mathrm{pH} 9$ of Bacillus sp. cell free broth from cultures grown in artificial seawater supplemented with $0.01 \%$ yeast extract and $1 \%$ ammonium sulfate at $30^{\circ} \mathrm{C}$ and $200 \mathrm{rpm}$.

During 48 hour culturing, we can also observed an increased in acidic proteases activities from cell-free broth of the bacterial culture assayed at pH 5 (Figure 4). During 48 hour culturing, $B$. pumilus produced highest activities of acidic protease followed by $B$. subtilis and $B$. licheniformis (Figure 4). The activities of $B$. pumilus and $B$. licheniformis acidic proteases started to decrease but the activity for $B$. subtilis continued to increase after being incubated for 96 hour (Figure 4). All Bacillus sp were shown to be able to utilize yeast extract and ammonia as nitrogen source and produce two types of extra-cellular proteases. Alkaline protease are being produced in the early growth of the bacteria while acidic protease are being produced at the later stage of the bacterial growth. Production of the alkaline and acidic proteases could be related to the assimilation of ammonia which is the sole source of nitrogen in the culture media. Microorganisms have evolved highly effective systems for nitrogen acquisition and efficient utilization of scarce resources to be able to survive in natural environments. Ammonia are being utilized to synthesize glutamate through two alternative ammonium assimilation pathways: one carried out sequentially by glutamine synthetase (GS) and glutamate synthase (GOGAT), and another catalyzed by glutamate dehydrogenase (GDH) (Chavez et al., 1999). Further studies on the relationship of production and regulation of the alkaline and acidic protease to ammonia assimilation are essential in order to understand how the Bacillus $s p$ could be used as bioremediator to reduce ammonia and improve water quality in shrimp ponds.

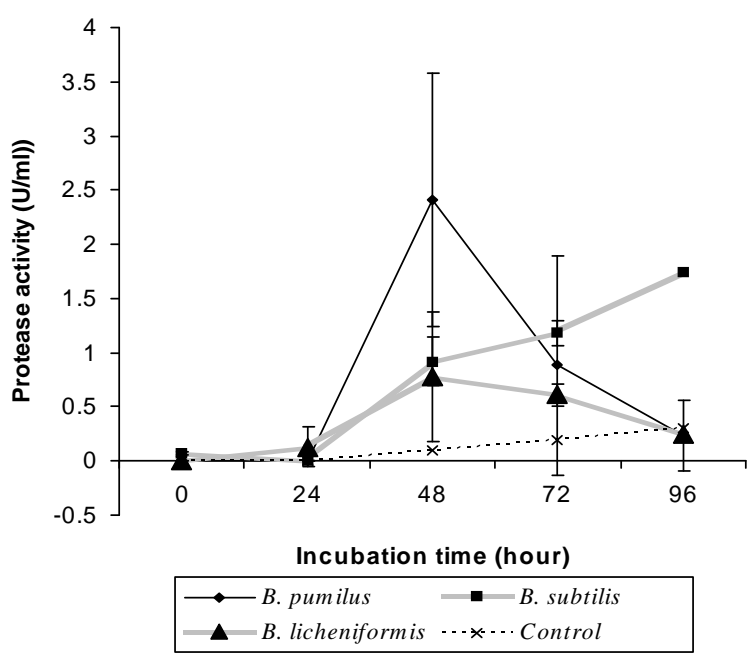

Figure 4:Protease activity at $\mathrm{pH} 5$ of Bacillus sp. cell free broth from cultures grown in artificial seawater supplemented with $0.01 \%$ yeast extract and $1 \%$ ammonium sulfate at $30^{\circ} \mathrm{C}$ and $200 \mathrm{rpm}$.

\section{ACKNOWLEDGEMENTS}

Authors are grateful to the Malaysian Government for providing funds through National Biotechnology Directorate (NBD) Project no. 54801 to carry out this research.

\section{REFERENCES}

Bach, H.J., Hartmann, A., Schloter, M. and Munch, J.C. (2001). PCR primers and functional probes for amplification and detection of bacterail genes for extracellular peptidases in single strains and in soil. Journal of Microbiological Methods. 44:173-182.

Brock, F. M., Forsberg, C. W. and Buchanan-Smith, J. G. (1982). Proteolytic of rumen microorganisms and effects of proteinase-inhibitors. Applied and Environmental Microbiology. 44:561-569.

Chavez, S., Lucena, J.M., Reyes, J.C., Florencio, F.J. and Candau, P. (1999). The presence of glutamate 
dehydrogenase is a selective advantage for the Cyanobacterium Snechocystis sp. strain PCC 6803 under nonexponential growth conditions. Journal of Bacteriology. 181(3):808-813.

Detsch, C. and Stulke, J. (2003). Ammonia utilization in Bacillus subtilis: transport and regulatory functions of $\mathrm{NrgA}$ and NrgB. Microbiology.149:3289-3297.

Devaraja, T. N., Yusoff, F. M. and Shariff, M (2002). Changes in bacterial populations and shrimp production in ponds treated with commercial microbial products. Aquaculture. 206:245-256.

Fleming, A.B., Tangney, M., Jorgensen, P.L., Diderrichsen, B and Priest, F. G. (1995). Extracellular enzymes synthesis in a sporulationdeficient strain of Bacillus licheniformis. Applied and Environmental Microbiology. 61(11):3775-3780.

Moriaty, D.J.W (1999). Disease control in shrimp aquaculture with probiotic bacteria. In Bell C.R., Brylinsky $M$ and Johnson-Green $P$ (eds) Proceedings of the $8^{\text {th }}$ International Symposium on Microbial Ecology, Atlantic Canada Society for Microbial Ecology, Halifax, Canada.
Rao, M.B., Tanksale, A. M., Ghatge, M.S. and Deshpande, V.V. (1998). Molecular and biotechnology aspects of microbial proteases. Microbiology and Molecular Biology Review. 62(3):597-635.

Straub, D.V. and Dixon, B.A. (1997). Evaluation of commercial products for the removal of nitrogenous waste products from water. Department of Biological Sciences,California State University, Hayward, CA 94542. 'http:///bióconlābs.com/bacteval.ht̄m|.

Valbuzzi, A., Ferrari, E. and Ābertini, A. M. (1999). A novel member of the subtilisin-like protease family from Bacillus subtilis. Microbiology. 145:3121-3127. 